\title{
PENGGUNAAN DIALIZER RE-USE PADA PASIEN HEMODIALISA TERHADAP NILAI UREA REDUCTION RATIO (URR) DI RUMAH SAKIT ADVENT BANDUNG
}

\author{
APPPLICATION OF DIALIZER RE-USE TO HEMODIALISA PATIENT TOWARDS \\ UREA REDUCTION RATIO IN BANDUNG ADVENTIST HOSPITAL
}

\author{
Angga Andreas Wantoro', Debilly Yuan Boyoh ${ }^{2}$ \\ Fakultas IImu Keperawatan, Universitas Advent Indonesia
}

\begin{abstract}
ABSTRAK
Pendahuluan: Pemakaian ulang dializer (Dializer Re-Use) merupakan suatu tindakan pemakaian dializer lebih dari satu kali pada pasien yang sama. Dializer setetah digunakan dalam proses hemodialisis dibersihkan dan dilakukan sterilisasi baik menggunakan mesin maupun manual. Pemakaian dializer secara ulang dapat menurunkan tingkat efektif karena berbagai alasan, diantaranya adalah terjadi penurunan nilai Urea Reduction Ratio (URR) sehingga tidak optimal bila dipakai untuk proses hemodialisis. Tujuan: Penelitian ini bertujuan untuk mengetahui apakah dializer reuse ke-7 masih layak digunakan kembali dengan hasil yang efektif. Metode: Desain penelitian yang digunakan adalah pra-experimental dengan disain one group pretest-posttest. Populasi penelitian ini adalah pasien yang menjalani terapi hemodialisa di Rumah Sakit Advent Bandung, sampel yang digunakan berjumlah 15 pasien yang di pilih secara purposive sampling. Hasil: Hasil penelitian ini menunjukan bahwa nilai rata-rata Urea Reduction Ratio pada dializer re-use ke-2 yaitu 71.00. Hasil nilai rata-rata Urea Reduction Ratio pada dializer re-use ke-7 adalah 67.40. Sehingga dapat disimpulkan adanya perbedaan pada nilai hasil Urea Reduction Ratio dengan nilai thitung adalah 1.020 dan nilai tabel adalah 1.771 yang artinya $H_{0}$ di tolak dan $H_{\alpha}$ diterima. Nilai hasil Urea Reduction Ratio dari pamakaian dializer re-use ke-7 masih di atas dari standart $\geq 65 \%$ yang berarti dializer pemakaian ke-7 masih dapat digunakan oleh pasien yang melakukan terapi hemodialisa. Diskusi: Bagi peneliti selanjutnya diharapkan untuk melakukan penelitian yang berkaitan dengan dializer re-use yang dilihat dari hasil Urea Reduction Ratio dengan perancu (jenis kelamin, usia, lama menjalani terapi hemodialisa) sehingga dapat menambah khazanah keilmuan yang lebih luas dan mendalam.
\end{abstract}

Kata kunci: dializer, hemodialisa, Urea Reduction Ratio

\begin{abstract}
Introduction: Reusing the dializer (Dializer Re-Use) is an action of using the dializer more than once in the same patient. The dialifier is used in the hemodialysis process to be cleaned and sterilized using either a machine or a manual. Regular use of dializers can decrease the effective level for many reasons, including the decline in the value of Urea Reduction Ratio (URR) so it is not optimal when used for hemodialysis process. Purpose: This study was to determine whether the $7^{\text {th }}$ re-use dialer is still feasible to be reused with effective results. Method: The research design was preexperimental research with one group pretest-posttest design. The population of this study were patients who performed hemodialysis therapy at Bandung Adventist Hospital, the sample used was 15 patients selected by purposive sampling. Result: The results of this study indicated that the average value of Urea Reduction Ratio in the second re-use dializer (2) is 71.00. The average value of Urea Reduction Ratio on the re-use dialer to seven is 67.40. The difference in value of Urea Reduction Ratio with tcount value is 1.020 and table value is 1.771 which means rejected and accepted. The value of Urea Reduction Ratio results from the use of the seventh reagent dialer $7^{\text {th }}$ is still above the standard $\geq 65 \%$ which means that the seventh usage dializer can still be used by the patient performing hemodialysis therapy. Discussion: For further research, it is expected to do research related to re-use dializer seen from Urea Reduction Ratio. With confounders (sex, age, duration of hemodialysis therapy). So it can add a wider and deeper scientific treasures.
\end{abstract}

Key words: dializer, hemodialysis, Urea Reduction Ratio
JURNAL SKOLASTIK KEPERAWATAN

$\mathrm{Vol}, 3$, No. 2

Juli-Desember 2017

ISSN: $2443-0935$ E-ISSN 2443 - 1699 


\section{PENDAHULUAN}

Dharmeizar (2012) mengatakan angka kejadian penyakit gagal ginjal kronis stadium 5 sejak 10-15 tahun belakangan ini semakin meningkat di seluruh dunia termasuk di Indonesia. Keadaan ini terutama disebabkan oleh makin banyaknya ditemukan penyakit diabetes mellitus dan hipertensi yang merupakan penyebab terbanyak terjadinya penyakit ginjal kronis stadium selain glomerulonephritis.

Roesli (2008) mengatakan penyakit gagal ginjal di Indonesia digambarkan sama seperti fenomena gunung es, dimana hanya sekitar $0,1 \%$ kasus yang terdeteksi, dan 11-16\% yang tidak terdeteksi. Menurut data statistik yang dihimpun oleh Perhimpunan Nefrologi Indonesia (PERNEFRI), jumlah pasien gagal ginjal di Indonesia mencapai 70.000 orang dan hanya sekitar 13.000 pasien yang melakukan cuci darah atau hemodialisis (sebagaimana dikutip pada buku Lubis, 2008).

Berdasarkan data dan informasi dari Pusat Perhimpunan Rumah Sakit Seluruh Indonesia, jumlah dari pasien gagal ginjal kronik diperkirakan sekitar 50 orang dari satu juta penduduk, $60 \%$ adalah pada usia dewasa dan pada usia lanjut. Menurut Depkes RI 2009, pada peringatan Hari Ginjal Sedunia bahwa sampai saat ini di Indonesia terdapat sekitar 70 ribu orang pasien gagal ginjal kronik atau $10 \%$ yang dapat melakukan cuci darah yang dibiayai program Gakin (Keluarga Miskin) dan PT. Askses (Asuransi Kesehatan) (Ratnawati, 2014). Hemodialisis merupakan terapi pengganti ginjal yang dilakukan 2-3 kali seminggu dengan lama waktu 4-5 jam, yang bertujuan untuk mengeluarkan sisasisa metabolisme protein dan mengoreksi gangguan keseimbangan cairan dan elektrolit. Proses terapi hemodialisis yang membutuhkan waktu selama 5 jam, umumnya akan menimbulkan stres fisik pada pasien setelah hemodialisis. Pasien akan merasakan kelelahan, sakit kepala dan keluar keringat dingin akibat tekanan darah yang menurun, sehubungan dengan efek hemodialisis. Selain itu kadar oksigen rendah karena anemia akan menyebabkan tubuh mengalami kelelahan yang ekstrem (fatigue) dan akan memaksa jantung bekerja lebih keras untuk mensuplai oksigen yang dibutuhkan (Cahyaningsih, 2009).

Pemakaian ulang dializer (Dializer ReUse) merupakan suatu tindakan pemakaian dializer lebih dari satu kali pada pasien yang sama. Dializer setelah digunakan dalam proses hemodialisis dibersihkan dan dilakukan sterilisasi baik menggunakan mesin maupun manual (Sukardi \& Rofii, 2013). Pemakaian dializer re-use di Indonesia mulai sekitar tahun 1998 sebagai dampak dari krisis moneter yang melanda Indonesia. Penelitian yang dilakukan Sudarmo (2010) menunjukan bahwa pemakaian dializer re-use hanya direkomendasikan pada pemakaian ke-4 dan ke-5 karena berbagai alasan, diantaranya adalah terjadi penurunan nilai Urea Reduction Ratio (URR) sehingga tidak optimal bila dipakai untuk proses hemodialisis.

National Kidney Foundation Kidney Disease Outcomes Quality Initiative (NKFKDOQI,2006) merekomendasikan bersihan ureum dinilai dengan efektif jika nilai URR $\geq 65 \%$ untuk pasien dengan dosis hemodialisis tiga kali perminggu dengan rentang waktu 4 jam setiap kali prosedur hemodialisis, atau nilai URR $\geq 80 \%$ untuk pasien dengan dosis hemodialisis dua kali perminggu 
dengan rentang waktu 4-5 jam setiap kali prosedur hemodialisis. Perhimpunan Nefrologi Indonesia (Pernefri, 2003) pada hemodialisis dengan frekuensi $2 \mathrm{x} /$ minggu dengan durasi hemodialisis 4-5 kali menyatakan bahwa bersihan ureum dinilai efektif jika dengan nilai URR $\geq 65$ $\%$ (Pernefri, 2003; NKF, 2006; Daugirdas, Blake dan Ing, 2007).

Evaluasi terhadap keefektifan terapi dialysis dinyatakan sebagai adekuasi dialysis yang dihitung dengan rumus $\mathrm{Kt} / \mathrm{V}$ atau URR. Dialisis yang adekuat berdampak pada kualitas hidup dan ratarata kelangsungan hidup pasien, tingkat morbiditas dan mortalitas pasien, besarnya biaya perawatan serta frekuensi hospitalisasi pasien (Gorman et al, 2006; Maoujud et al, 2012). Tingkat morbiditas, mortalitas, frekuensi hospitalisasi, lama rawat di rumah sakit dan kualitas hidup menjadi indikator mutu pelayanan ruang hemodialysis, yang termasuk ruang perawatan intensif dan pasien dengan kondisi kritis.

Hasil observasi selama peneliti melakukan praktek belajar di ruang hemodialisa, didapatkan bahwa pengguna dializer masih seringkali digunakan berulang. Hingga pada saat ini rumah sakit masih menggunakan pemakaian ulang dializer (dializer reuse) pada proses hemodialisa yang di lakukan oleh pasien gagal ginjal dengan program yang sama. Hal ini disebabkan oleh karena harga dializer yang cukup mahal, dan belum pernah dilakukannya penelitian mengenai dializer re-use maka peneliti tertarik untuk melakukan penelitian dengan judul "Penggunaan Dializer Re-use pada Pasien Hemodialisa Terhadap Nilai Urea Reduction Ratio (URR) di RSA Bandung."

\section{TUJUAN PENELITIAN}

Tujuan umum dari penelitian ini adalah untuk mengetahui apakah dializer reused ke-7 masih layak digunakan kembali dengan hasil nilai urea yang efektif.

\section{MANFAAT PENELITIAN}

Hasil penelitian ini diharapkan menjadi salah satu acuan bagi mahasiswa atau tamatan keperawatan untuk mempelajari tentang efektivitas dializer re-use terhadap nilai hasil urea.

\section{BAHAN DAN METODE}

Penelitian ini adalah praexperimental dengan disain penelitian one group pretest-posttest. Variabel dependent yaitu nilai Urea Reduction Ratio (URR) yang didapat dari hasil darah dari penggunaan dializer re-use.

Populasi yang digunakan dalam penelitian ini berjumlah 15 responden yang menjalani hemodialisa di Unit Hemodilisis Rumah Sakit Advent Bandung. Sampel dalam penelitian dipilih menggunakan tehnik purposive sampling.

Sample yang benar-benar memenuhi kriteria pada saat pengumpulan data adalah 15 orang dari 20 orang yang direncanakan.

Adapun prosedur yang dilakukan dalam proses pengumpulan adalah sebagai berikut:

1. Menjelaskan prosedur kepada pasien dan meminta ijin kepada kepala unit hemodialisa untuk melakukan penelitian.

2. Memilih responden sesuai dengan kriteria yang sudah ditentukan. 
3. Mengumpulkan data berupa nilai urea sebelum melakukan hemodialisa sesuai dengan responden yang ditentukan.

4. Menghitung menggunakan rumus Urea Reduction Ratio (URR) untuk mendapatkan hasil dari urea level yang pertama (sebelum melakukan hemodialisis)

5. Setelah pasien selesai melakukan hemodialisis data dari pasien seperti, urea akan kembali di kumpulkan dan di ambil untuk mengetahui hasilnya dengan menggunakan rumus Urea Reduction Ratio (URR).

6. Data di dapat dari hasil urea dializer re-use kedua dan yang ketujuh dengan rumus yang sama.

7. Setelah mendapat semua data dari hasil hemodialisa pada responden, peneliti mengucapkan terima kasih pada responden

\section{HASIL PENELITIAN}

Hasil penelitian diperoleh melalui eksperimen dengan one group pre testpost test dari 15 orang subjek. Subjek yaitu terdiri dari 15 orang pasien yang melakukan terapi hemodialisa di Rumah Sakit Advent Bandung dengan ketentuan minimal time Dialyzer empat sampai lima jam dengan Quick blood lebih dari sama dengan duaratus dan pasien hemodialisa yang menjalani terapi dua sampai tiga kali seminggu. Data yang dikumpulkan diolah untuk menjawab identifikasi masalah pertama sampai ketiga.

\section{Urea Reduction Ratio pada penggunaan dializer ke-2}

Permasalahan yang diidentifikasi pertama yaitu "Berapakah hasil Urea Reduction Ratio pada penggunaan dializer ke-2?". Untuk mengetahui hasil nilai Urea Reduction Ratio dari penggunaan dializer ke dua maka dilakukan penilaian yang kemudian dipresentasikan dan dilihat rata-ratanya.

\section{Urea Reduction Ratio pada penggunaan dializer ke-7}

Permasalahan yang diidentifikasi pertama yaitu "Berapakah hasil Urea Reduction Ratio pada penggunaan dializer ke-7?". Untuk mengetahui hasil nilai Urea Reduction Ratio dari penggunaan dializer ke tujuh maka dilakukan penilaian yang kemudian dipresentasikan dan dilihat rata-rata nilai Urea Reduction Ratio dari 15 subyek tersebut seperti pada identifikasi masalah nomor satu.

Tabel 1. Hasil Urea Reduction Ratio dializer re-use ke-7 kali.

\begin{tabular}{ll}
\hline $\mathrm{N}$ & Mean \\
\hline 15 & 67.40 \\
\hline
\end{tabular}

Tabel 1. Menunjukkan bahwa responden $(\mathrm{n}=15)$ di unit hemodialisa Rumah Sakit Advent Bandung memiliki hasil nilai Urea Reduction Ratio dengan rata-rata $67.40 \%$.

\section{Perbedaan yg signifikan pada penggunaan dializer re-use terhadap hasil Urea Reduction Ratio dari dializer kali ke-dua dan kali yang ke-7.}

Adapun ketentuan uji hipotesis yang digunakan untuk menentukan identifikasi masalah ketiga menggunakan uji t. Untuk menguji ada tidaknya pengaruh positif yang signifikan, nilai $t_{\text {hitung }}$ dibandingkan dengan nilai $t_{\text {tabel }}$ digunakan taraf signifikansi sebesar 5\%. Adapun uji t yang digunakan adalah Paired Samples karena sample yang digunakan adalah sama yaitu responden yang mengikuti program hemodialisa rutin. 
Tabel 2. Hasil Perhitungan Uji tberpasangan

\begin{tabular}{|c|c|c|c|}
\hline $\begin{array}{c}\text { Paired } \\
\text { Differences }\end{array}$ & $\mathrm{T}$ & $\mathrm{df}$ & $\begin{array}{l}\text { Sig. } \\
\text { tailed) }\end{array}$ \\
\hline Upper 40 & & & $\begin{array}{l}95 \% \\
\text { Confidenc } \\
\text { e Interval } \\
\text { of the } \\
\text { Differenc } \\
\text { e }\end{array}$ \\
\hline Pair 111.172 & 1.02 & 1 & .325 \\
\hline $\begin{array}{l}\text { URR_ReUse } \\
2\end{array}$ & 0 & 4 & \\
\hline $\begin{array}{l}\text { URR_ReUse } \\
-7\end{array}$ & & & \\
\hline
\end{tabular}

Tabel 2. Dari hasil pengolahan data pada table 3 didapat nilai thitung adalah 1.020 dan nilai $t_{\text {tabel }}$ adalah 1.771. Nilai signifikasi $0.325>0.05$. Sunyoto (2012) mengatakan pada kriteria pengujian dua pihak, bila $t_{\text {hitung }}<t_{\text {tabel }}$ maka $\mathrm{H}_{\alpha}$ diterima dan $t_{\text {hitung }}$ adalah harga mutlak, sedangkan bila $t_{\text {hitung }}>t_{\text {tabel }}$ maka $\mathrm{H}_{o}$ diterima. Tidak dilihat (+) atau (-), dimana tabel dicari dari tabel distribusi ' $t$ ". ttabel dapat diperoleh dengan menetapkan tingkat signifikan $95 \%(\alpha)$ atau 0.05

\section{PEMBAHASAN}

\section{Urea Reduction Ratio pada penggunaan dializer ke-dua}

Urea Reduction Ratio (URR) adalah pengurangan urea sebagai akibat dari dialisis. Urea Reduction Ratio (URR) adalah salah satu ukuran seberapa efektif pengobatan dialisis yang kerjanya adalah untuk membuang sisasisa metabolism dari tubuh dan umumnya dinyatakan sebagai presentase.

Nilai Urea Reduction Ratio pasien berkisar $71 \%$ yang masih terbilang normal dan efektif, merupakan nilai hasil yang didapatkan dari hasil urea yang kemudian dihitung menggunakan rumus Urea Reduction Ratio. Hal ini sangat mudah dilakukan karena data yang di dapat langsung dari laboratorium. National Kidney Foundation Kidney Disease Outcomes Quality Initiative (NKFKDOQI, 2006) merekomendasikan bersihan ureum dinilai dengan efektif jika nilai URR $\geq 65 \%$ untuk pasien dengan dosis hemodialisis tiga kali perminggu dengan rentang waktu 4 jam setiap kali prosedur hemodialisis, atau nilai URR $\geq 80 \%$ untuk pasien dengan dosis hemodialisis dua kali perminggu dengan rentang waktu 4-5 jam setiap kali prosedur hemodialisis. Persentase di atas $71 \%$ masih terbilang normal dan masih efektif karena nilai standar yang tercantum adalah $65 \%$.

\section{Urea Reduction Ratio pada penggunaan dializer ke-tujuh}

Dari tabel 2 di atas dapat terefleksi bahwa rata-rata nilai Urea Reduction Ratio yang merupakan hasil urea dari pasien hemodialisa di Rumah Sakit Advent Bandung 67.40 dengan jumlah pasien sebanyak 15 orang. Hal ini menunjukkan bahwa terdapat penurunan nilai dari hasil urea sebesar $3.60 \%$. Penurunan ini diakibatkan oleh karena dializer dilakukan secara berulang. Ratnawati (2014) mengatakan bahwa umumnya dializer dapat digunakan kembali apabila volume dializer masih $60 \%$ sampai dengan $70 \%$ dari dializer baru. Perhimpunan Nefrologi Indonesia (Pernefri, 2003) pada hemodialisis dengan frekuensi $2 \mathrm{x} /$ minggu dengan durasi hemodialisis 4-5 kali menyatakan bahwa bersihan ureum dinilai efektif jika dengan nilai URR $\geq 65 \%$. Persentase diatas $67 \%$ masih terbilang normal dan masih efektif karena nilai standar yang tercantum adalah $65 \%$ 
3. Perbedaan yg signifikan pada penggunaan dializer re-use terhadap hasil Urea Reduction Ratio dari dializer ke-dua dan yang ke-tujuh

Analisis dari uji statistik menunjukkan bahwa terdapat perbedaan rata-rata nilai Urea Reduction Ratio pemakaian ulang ke dua dan pemakaian ke tujuh tidak signifikan. Nilai Urea Reduction Ratio dari dializer re-use ke dua yang ratarataya adalah 71.00 dengan standar deviasi 7.764 .

Sedangkan pada hasil pemeriksaan yang ke tujuh persentase nilai rata-rata menurun menjadi 67.40 dengan standart deviasi 14.327. Menurut Sukandar (2006), persentase diatas $67 \%$ masih terbilang normal dan masih efektif karena nilai standar yang tercantum adalah $65 \%$.

Penurunan hasil nilai Urea Reduction Ratio pasien hemodialisa Rumah Sakit Advent Bandung secara tidak signifikan menurun. (Ratnawati, 2014) Dializer reuse merupakan penggunaan dializer lebih dari satu kali pada pasien yang sama. Umumnya dializer dapat digunakan kembali apabila volume dializer masih $60 \%$ sampai dengan $70 \%$ dari dializer baru. Pemakaian Dializer re-use pertamakali dilaporkan pada tahun 1964. Sejak saat itu, Dializer reuse telah banyak digunakan di beberapa negara. Data dari catatan medis tahun 2007 di Unit Hemodialisa RSCM didapatkan $96 \%$ pasien Hemodialisa menggunakan Dializer re-use. Dializer yang telah digunakan dapat dipakai kembali setelah dilakukan hemodialisa dengan menggunakan dializer yang telah dipakai, kemudian dializer tersebut bisa terbilang tidak layak pakai ketika nilai dari hasil ureum < dari 65\%. Maka dari itu dilakukan pemeriksaan ureum setelah dan sebelum melakukan tindakan hemodialisa pada kadar darrah pasien untuk mendapatkan nilai hasil dari Urea Reduction Ratio, maka setelah itu barulah dializer tersebut masih layak pakai atau tidak.

National Kidney Foundation Kidney Disease Outcomes Quality Initiative (NKFKDOQI,2006) merekomendasikan bersihan ureum dinilai dengan efektif jika nilai URR $\geq 65 \%$ untuk pasien dengan dosis hemodialisis tiga kali perminggu dengan rentang waktu 4 jam setiap kali prosedur hemodialisis, atau nilai URR $\geq 80 \%$ untuk pasien dengan dosis hemodialisis dua kali perminggu dengan rentang waktu 4-5 jam setiap kali prosedur hemodialisis.

Dari hasil pengujian uji t didapatkan nilai $\mathrm{t}_{\text {hitung }}$ sebesar 1.020 dengan $\mathrm{t}_{\text {tabel }}$ sebesar 1.771 dan nilai signifikasi 0.325 lebih besar dari 0.05 yang artinya terdapat perbedaan antara rata-rata nilai antara penggunaan dializer ke dua dan penggunaan dializer ke tujuh secara tidak signifikan. Melakukan tindakan hemodialisa adalah salah satu cara yang efektif untuk memperpanjang kehidupan pasien yang telah menderita penyakit gagal ginjal kronis. Karena mahalnya biaya melakukan hemodialisa maka dilaukanya tindakan dializer re-use yaitu pemakaian dializer secara berulang setelah pemakaian pertama. Akan tetapi dializer yang digunakan berulangkali secara perlahan akan menurun tingkat efektifitasannya, maka dari itu dilakukannya uji laboratorium yaitu melihat kadar ureum dalam darah untuk mengetahui apakah masih terbilang eektif atau tidak. Pemeriksaan ureum ini dilakukan pada saat sebelum melalukan tindakan hemodialisa dan sesudah melakukan tindakan hemodialisa yang diambil melalui sampel berupa darah pasien yang melakukan tindakan hemodialisa. 
Setelah itu barulah didapatkan hasil dari nilai Urea Reduction Ratio yang dihitung dari hasil urea sebelum dan sesudah dilakukan tindakan hemodialisa. Semakin tinggi hasilnya maka dializer tersebut masih terbilang layak pakai akan tetapi jika hasil Urea Reduction Ratio < dari 65\% maka dializer tersebut bisa terbilang tidak layak dipakai oleh pasien karena pada saat melakukan tindakan hemodialisa dializer tersebut tidak memaksimalkan tugasnya untuk mengurangi kadar ureum dalam darah pasien gagal ginjal kronis sehingga malah memperparah pasien dalam kehidupannya.

Sisi positif dari penelitian ini adalah untuk mengetahui apakah dializer yang digunakan secara berulang ini masih bisa dikatakan dalam kondisi yang baik dalam arti lain dializer tersebut masih layak untuk dipakai untuk terapi hemodialisa. Adekuasi dialisis adalah kecukupan jumlah proses dialisis untuk menjaga dan menjamin kondisi optimal dan terbaik pada pasien uremik untuk mencegah komplikasi akibat penumpukan toksin uremik (Djarwoto, 2009). Ringoir dan Vanholder (1992) mendefinisikan adekuasi adalah kemampuan untuk membersihkan darah dan menyeimbangkan jumlah cairan guna mendekati fungsi ginjal secara normal.

Evaluasi terhadap keefektifan terapi dialysis dinyatakan sebagai adekuasi dialysis yang dihitung dengan rumus $\mathrm{Kt} / \mathrm{V}$ atau URR. Dialisis yang adekuat berdampak pada kualitas hidup dan ratarata kelangsungan hidup pasien, tingkat morbiditas dan mortalitas pasien, besarnya biaya perawatan serta frekuensi hospitalisasi pasien (Gorman et al, 2006; Maoujud et al, 2012).

\section{KESIMPULAN}

Baik buruknya kinerja dapat dipengaruhi oleh keadaan mesin maupun pasien yang melakukan hemodialisa. Ketika dializer bekerja dengan baik maka kehidupan dari pasien penderita gagal ginjal kronis akan semakin lama, oleh karna itu dializer yang efektif sangat menjamin kehidupan pasien gagal ginjal. Semakin banyak urea yang dibuang dalam kadar darah pasien maka akan semakin baik dan pasien akan merasa lebih nyaman.

\section{DAFTAR PUSTAKA}

Arif Muttaqin dan Kumala Sari. (2011). Asuhan keperawatan gangguan system perkemihan. Jakarta: Salemba Medika.

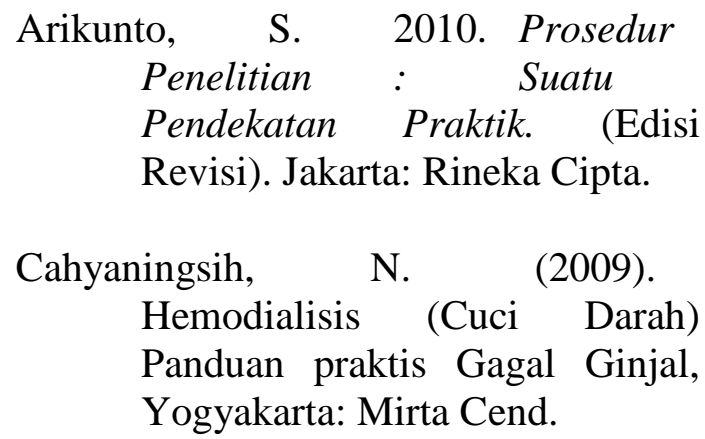

Christense, P. J., Kenney, J. W. 2009. Proses Keperawatan: Aplikasi Model Konseptual Jakarta: Buku Kedokteran EGC.

Daugirdas, J.T, Blake, P.G, \& Ing, T.S. (2007). Handbook of dialysis (4th ed). Lippincott: Philadelphia.

Daugirdas, J. T., Thomas, A. D., Greene, T., Levin, N.M., Chertow, G. M, \& Rocco, M.V., et al. (2009). Standard Kt/V: a method of calculation that includes effects of fluid removal and residual kidney clearance. International Society of Nephrology, 77, 637- 
644. Diperoleh dari http://www.kidneyinternational.o rg.

Daymond, C. (2008). Metodemetode

Riset Kualitatif Dalam Public Relation dan Marketing Communications. Yogyakarta: Bentang

Dewi, L. (2008). Need Assesment Pengembangan pelayanan pekerja social Medis terhadap pasien gagal ginjal terminal di RS Ny.R. A Habibie Bandung.

Dharmeizar. (2012). Naskah Lengkap Simposium Nasional

Peningkatan Pelayanan Penyakit Ginjal Kronik dan Indonesia Renal Registry. Yogyakarta: Pernefri Wilayah Yogyakarta.

Gorman G, Furth S, Hwang W, Parekh R, Astor B, Barbara FB, et al, 2006, Clinical Outcomes and Dialysis Adequacy in Adolescent Hemodialysis Patients, American Journal of Kidney Diseases, 47 (2), pp.285-293.

Guyton \& Hall. (2014). Buku Ajar Fisiologi Kedokteran.edisi 12. Jakarta: EGC.

Hidayat, A. 2007. Metode penelitian keperawatan dan teknik analisa data. Jakarta: Gramedia Pustaka Utama.

I Ketut Swarjana. (2012). Metedologi Penelitian Kesehatan. Yogyakarta: Andi.

Jamerson, J. L., \& Loscalzo, J. (2013). Nefrologi dan Gangguan Asam Basa. Jakarta: EGC.
Lawrence, J. L. (2016). Oxford Handbook of Dialysis:

Edition 4. United Kingdom: Oxford University Press.

Leypoldt, J. K., Culleton, B, F., \& Cheung, A. $\mathrm{K}$ (2010). Hemodialisys Adequacy, dalam Himmelfarb, J., \& Sayegh, M. H, (Penyunting) "Chronic Kidney Disease, Dialysis and Transplantation". Philadelphia: Saunders Elsevier.

Muttaqin, A., \& Sari, K. (2011). Asuhan keperawatan gangguan system perkemihan. Jakarta: Salemba Medika.

Nissenson, A. R., \& Fine, R. E. (2016). Handbook of Dialysis Therapy: Edition 5. Philadelphia: Elsevier.

Novoa, J.M.L., Salgado, C.M., Pena, A.B.R., Hernandez, F.J.L. 2010. Common pathophysiological mechanisms of chronis kidney disease: Therapeutic perspectives. Pharmacology \& Therapeutics 128 (2010) 61-81.

Nurarif \& Kususma. (2013). Aplikasi Asuhan Keperawatan Berdasarkan Diagnosa dan NANDA NIC NOC. Jilid 2. MedAction.

Nursalam. (2008). Konsep Dan Penerapan Metodologi Penelitian Ilmu keperawatan Edisi 2. Jakarta: Salemba Medika.

Piontkowski, J. (2007). AAMI Recomendations for Reuse of Dialyzers. 
Purnomo, Basuki B, 2011. Dasardasar Urologi. Sagung Seto: Jakarta. Ratnawati. (2014). Efektivitas Dialiser Proses Ulang (DPU) pada Penderita Gagal Ginjal Kronik (Hemodialisis).

Ridwan. (2008). Metode Penelitian Kuantitatif dan $R \& D$. Bandung: Alfabeta.

Roesli, R., (2008). Hipertensi, diabetes, dan gagal ginjal di Indonesia. Dalam: Lubis, H.R., et al (eds). 2008. Hipertensi dan Ginjal. USU Press, Medan: 95-108.

Santoso, S. (2009). Panduan Lengkap Menguasai Statistik Dengan SPSS 17 Jakarta: Penerbit PT Elex Media Kompitudo.

Smeltzer, S. C., \& Bare, B. G. (2011). Buku ajar keperawatan medical bedah. Brunner \& Suddarth. Edisi. Jakarta: EGC.

Sudarmono E. (2010). Perbandingan kliren-n dan Rasio

Penurunan Urea-n antara ginjal buatan (dializer) Baru dan pakai berulang. Repository Universitas Diponegoro.
Sugiyono. (2014). Metode Penelitian Kuantitatif dan Kualitatis dan $R$ $\& D$. Bandung. Alfabeta.

Sukardi, \& Rofii, M. (2013). Pemakaian Dialiser Reuse Yang Layak Digunakan Pada Pasien Dengan Hemodialisa. 9.

Sunyoto Danang. (2012). Stat54rfvbgfx 8/tistik Kesehatan analisa kesehatan analisis data dengan perhitungan manual dan program SPSS. Yogyakarta: umed.

Sukandar, E. (2006). Gagal Ginjal dan Panduan Terapi Dialisis. Bandung: Fakultas Kedokteran Universitas

Padjadjaran (2013). Neferologi Klinik edisi IV. Bandung: $\quad$ Fakultas Kedokteran UNPAD.

Swarjana, I Ketut. 2012. Metodologi Penelitian Kesehatan. Yogyakarta. CV ANDI OFFSET.

Wijaya, Andra Saferi dan Putri, Yessie Mariza. (2013). Keperawatan Medikal Bedah 1. Yogyakarta: Nuha Medik 
